\title{
THE AMOUNT OF WATER SHOULD BE APPLIED FOR FABA BEAN CROP UNDER DRIP AND DEFICIT IRRIGATION. El-Hadidi,M.E. ${ }^{(1)}$;Samia M.EL-Marsafawy ${ }^{(2)}$ and I.M. Abdel- Fattah ${ }^{(3)}$. (1) Soils Dept., Fac. Of Agriculture, Mansoura university. \\ (2) Climate change Information center (CCIC), Agric. Res. Center (ARC). (3) Soils, Water \& Environment Research Institute (SWERI, ARC).
}

\begin{abstract}
A field experiment was carried out during the two successive growing seasons of faba bean 2011/ 2012 and 2012/ 2013.

The aim of this investigation was to find out the impact of water deficit based on differentreference evapotranspiration( $\mathrm{ET}_{\mathrm{o}}$ ) methods on water applied for faba bean crop.

The field trial was executed at Sakha Agricultural Research Station, which represents the conditions of North Nile Delta region. The field is clay in texture and furnished with drip irrigation system.

Main treatments were ET。 methods;FAO Penman-Monteith, Ibrahim, Doorenbos- Pruitt and Modified Penman. While the subtreatmentswere levels of watering, $60 \%, 80 \%$ and $100 \%$ from irrigation water (IW.), IW= crop water needs $\left(E_{\mathrm{c}}\right)$ divided by $E_{i}\left(E_{i}=\right.$ irrigation efficiency $=0.85$ for drip irrigation.

The main findings could be summarized as follows:

- Average seasonal irrigation water (IW) was ranged between 476.83and $696.41 \mathrm{~m}^{3}$ / fed.which recorded under 60\% FAO penman- monteith and $100 \%$ modified Penman, respectively.

- Mean rainfall (RF) of the two seasons were $405.08 \mathrm{~m}^{3} / \mathrm{fed} .(9.65 \mathrm{~cm})$.

- Average of the total water applied (TWA) had the same trend of IW and ranged between 881.92 and $1101.50 \mathrm{~m}^{3} /$ fed. for the stated $\mathrm{ET}_{\mathrm{T}}$ methods, respectively.

- The contribution percentage of RF in WA was between 36.8 and $46 \%$ which resulted from 100\% Modified Penman and the 60\% FAO Penman- Monteith, respectively.

- Generaly, ET. methods can be arranged in inscending order regarding computation of IW as; FAO Penman- Monteith,Doorenbos\&Pruit, Ibrahim and Modified Penman respectively.

Therefore,seasonal rate of water applied is ranged between 5.7 and $7.1 \mathrm{~m}^{3}$ / $\mathrm{fed} /$ day. Out of them, almost half of it comes from rainfall.

So, more investigations should be carried out to verifying the role of rainfall in North Nile Delta in water applied for cultivated winter crops as wheat, barley and sugar beet under drip irrigation.

Since there is no significant difference in seed yield, then it is advisable to irrigate with $60 \%$ FAO Penman- Monteith or Ibrahim depending upon the availability of climatic elements.

Keywords: drip irrigation, reference evapotranspiration (ETo), rainfall, water applied and faba bean.
\end{abstract}

\section{INTRODUCTION}

Egypt is facing a shortage of water and is expecting a serious decreasing of the availability of water. It is preferableto highlight the status of water in Egypt as follows(Abu-Zeidand Hamdy.2002): 
- Egypt is the solely country worldwide that its agricultural land is nearly irrigated of about $98 \%$ due to the very dry conditions i.e. no rainfed agriculture from economical point of view is implemented.

- Capita share per annum from water for different purposes is less than the poverty edge of $1000 \mathrm{~m}^{3}$ and it is continuously decreasing till the water scarcity level of less than $500 \mathrm{~m}^{3}$ in the few coming decades.

- River Nile is the main resource of renewal water with a fixed allocation of its water.

- Agriculture is the main sector in water consumption withabout $80-85 \%$ from total available water supply.

- Moreover, the negative impacts of climate change is expecting which is mainly resulting in increasing crop water needs along with decreasing crop production is expecting.

- Therefore, the strategic procedures of water saving becomes a must.

Furthermore,Phocaides (2007) had pointed out that drip irrigation is an effective way in water saving in specific and in " on- farm irrigation management" in general.

In addition, computation of irrigation water should be applied not less not more than the actual crop- water needs is also important item under the umbrella of " On - farm irrigation management".

In this direction, water deficit technique plays a vital role in rationalize irrigation water, particularly under the shortage of irrigation water.

Faba bean is considered as the main winter legume crop in Egypt. The high seed protein content of $28 \%$ gave this crop high value in human cnsumption and at the same time it is alow price source of plant protein.In addition,faba bean increased soil fertility through nitrogen fixation by root nodules. Such feature is amounted with $20-25 \mathrm{Kg} . \mathrm{N} / \mathrm{fed}$, to be useful for the following summer cultivated crop.(Ashry et al., 2012).

The role of water deficit and drip irrigation on faba bean crop- water needs were investigated by several researchers such as; Ibrahim (1981), Mashari and Naeem (2008), Ali and Talukder (2008), Oweis and Hachuns (2006), Kijne et al. (2003) provide several strategies for enhancement of water productivity by integrating varietal improvement and better resources management at plant level, field level and agro climatic level.

So, the objective of this work was to find out the impact of water deficit computed based on different reference evapotranspiration (ET。 methods for faba bean crop under drip irrigation method, In this direction, the sharing of rainfall in water applied was also taking into consideration.

\section{MATERIALS AND METHODS}

\section{Location}

A field experiment was conducted during the two successive winter growing seasons of 2011/2012 and 2012/ 2013 at the Demonstration Field for Modern Irrigation Systems, Sakha Agricultural Research Station, Kafr ELSheikh Governorate. The location is situated at 310-7' N Latitude, 30-57' E Longitude with an elevation of about 6 meters above mean sea level and 
represents the circumstances and conditions of Middle North Nile Delta region.

\section{Climatic conditions}

Climatological elements during the two growing seasons of faba bean (viciafaba L) crop were recorded as monthly averages from Sakha Agrometeorological Station.(Table 1)

Table(1).Climatic elements; average air temperature (T, Co), average relative humidity $(\mathrm{RH}, \%)$, wind speed at 2 meter height (U2, $\mathrm{m} . \mathrm{sec}-1)$ and rain fall (Rf,mm.) during the two growing seasons, 2011/2012 and 2012/ 2013.

\begin{tabular}{|l|c|c|c|c|c|c|c|c|}
\hline Month & \multicolumn{4}{|c|}{$\mathbf{2 0 1 1 / 2 0 1 2}$} & \multicolumn{4}{c|}{$\mathbf{2 0 1 2 / 2 0 1 3}$} \\
\cline { 2 - 9 } & T,Co & $\begin{array}{c}\text { RH, } \\
\text { \% }\end{array}$ & $\begin{array}{c}\text { U2, } \\
\text { m.sec-1 }\end{array}$ & $\begin{array}{c}\text { Rf } \\
\text { mm/day }\end{array}$ & T,Co & $\begin{array}{c}\text { RH, } \\
\%\end{array}$ & $\begin{array}{c}\text { U2, } \\
\text { m.sec-1 }\end{array}$ & $\begin{array}{c}\mathbf{R f} \\
\text { mm/day }\end{array}$ \\
\hline Nov & 16.9 & 70.5 & 0.76 & - & 20.40 & 75.67 & 0.66 & 28.2 \\
\hline Dec & 13.4 & 73.6 & 0.69 & 14.59 & 15.96 & 72.8 & 0.73 & 13.15 \\
\hline Jan & 9.32 & 68.95 & 0.72 & 32.5 & 13.42 & 78.21 & 0.52 & 2.54 \\
\hline Feb & 10.42 & 68.81 & 0.78 & 32.74 & 14.78 & 76.97 & 0.73 & - \\
\hline Mar & 13.17 & 68.52 & 1.06 & 42.75 & 18.51 & 65.16 & 1.03 & - \\
\hline Apr & 18.03 & 63.53 & 1.16 & - & 20.96 & 59.05 & 1.11 & 8.5 \\
\hline
\end{tabular}

\section{Soil analysis:}

To judge perfectly on the soil physical and chemical properties, these methods were used according to the global standard methods.

- Mechanical analysis for soil was carried out using the pipette method as described by Dewis and Fertias (1970).

- Bulk density was determined by using the undisturbed core samples according to Klute (1986).

- Soil organic matter content was determined by walkley and black method described by Hesse (1971).

- Total carbonates were estimated using modified calcimeter and calculated as calcium carbonate according to Dewis and Feritas, (1970).

- Soil reaction $(\mathrm{pH})$ was measured in (1:2.5) soil: water suspension (Jackson 1967).

Total soluble salts were determined by measuring the electrical conductivity in the extract of saturated soil paste in $\mathrm{dSm}^{-1}$ as explained by Jackson ,(1967).

- The amounts of water soluble cations and anions were determined in the extract of saturated soil paste by the methods described by Hesse, (1971).

1- Soluble calcium and magnesium $\left(\mathrm{Ca}^{++}\right.$and $\left.\mathrm{Mg}^{++}\right)$were determined by the versenate method.

2- Soluble sodium and potassium $\left(\mathrm{Na}^{+}\right.$and $\left.\mathrm{K}^{+}\right)$were determined by using Flamephotometer.

3- Carbonate and bicarbonate $\left(\mathrm{CO}_{3}^{--}\right.$and $\left.\mathrm{HCO}_{3}{ }^{-}\right)$were determined by titration with standarized sulfuric acid solution.

4- Chloride $\left(\mathrm{CL}^{-}\right)$was titrated with silver nitrate. 
5- Sulphate was determined by calculating the difference between sum of cations and anions.

- Field capacity and wilting point were measured by using pressure membrane apparatus according to (Garcia 1978).

The experimental soil is clay in texture( Dewis and Fertias, 1970) as presented in Table (2).

Table (2-a).Particle size distribution .

\begin{tabular}{|l|c|c|c|c|c|c|}
\hline $\begin{array}{l}\text { Soil } \\
\text { depth, } \\
\text { cm }\end{array}$ & $\begin{array}{c}\text { Clay, } \\
\%\end{array}$ & $\begin{array}{c}\text { Silt, } \\
\%\end{array}$ & $\begin{array}{c}\text { Coarse } \\
\text { Sand,\% }\end{array}$ & $\begin{array}{c}\text { Fine } \\
\text { Sand,\% }\end{array}$ & $\begin{array}{c}\text { Texture } \\
\text { grade }\end{array}$ & $\begin{array}{c}\text { O.M. } \\
\%\end{array}$ \\
\hline $0-15$ & 41.6 & 39.8 & 4.1 & 14.6 & Clay & 1.9 \\
\hline $15-30$ & 40.0 & 39.5 & 4.5 & 16 & Clay & 1.4 \\
\hline $30-45$ & 39.5 & 41.3 & 4.3 & 14.9 & Clay & 0.62 \\
\hline $45-60$ & 40.3 & 42.0 & 4.5 & 13.2 & Clay & 0.75 \\
\hline
\end{tabular}

Table (2-b).Soil chemical analysis.

\begin{tabular}{|c|c|c|c|c|c|c|c|c|c|c|c|}
\hline \multirow{2}{*}{\begin{tabular}{|l} 
Soil \\
depth \\
(cm)
\end{tabular}} & \multicolumn{4}{|c|}{ Cations, meq/l } & \multicolumn{4}{|c|}{ Anions, meq/l } & \multirow{2}{*}{$\begin{array}{c}\mathrm{EC}, \\
\mathrm{ds} / \mathrm{m}\end{array}$} & \multirow[t]{2}{*}{$\mathrm{pH}$} & \multirow[t]{2}{*}{$\mathrm{CaCO}_{3}$} \\
\hline & $\mathrm{K}^{+}$ & $\mathrm{Na}^{+}$ & $\mathrm{Mg}^{++}$ & $\mathrm{Ca}^{++}$ & $\mathrm{SO}_{4}^{-}$ & $\mathrm{Cl}^{-}$ & $\mathrm{HCO}_{3}{ }^{-}$ & $\mathrm{CO}_{3}{ }^{--}$ & & & \\
\hline-15 & 3.91 & 21.2 & \begin{tabular}{|l}
3.79 \\
\end{tabular} & \begin{tabular}{|l|l}
11.1 \\
\end{tabular} & 5.3 & 30.1 & 4. & 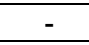 & 4.35 & 8.11 & 35 \\
\hline $15-3$ & 2.22 & \begin{tabular}{|l|}
9.3 \\
\end{tabular} & \begin{tabular}{|l|}
2.47 \\
\end{tabular} & 3.01 & 2.29 & 12.8 & 1. & - & 1.89 & 8.19 & 4.2 \\
\hline & 5.12 & \begin{tabular}{|l|l}
18.7 \\
\end{tabular} & \begin{tabular}{|l|}
4.98 \\
\end{tabular} & 5.2 & 3.89 & .2 & 2.5 & & 3.4 & 8.15 & 3.3 \\
\hline $45-60$ & 4.2 & 20.1 & 3.6 & 6.3 & 2.6 & 27.9 & 3.7 & - & 3.62 & 7.92 & 4.1 \\
\hline
\end{tabular}

\section{Soil water constants}

Values of soil- water constants; field capacity (FC, \%), wilting point (WP, \%), available water (AW, \%) as well bulk density $\left(\mathrm{D}_{\mathrm{b}}, \mathrm{Kg}^{-3} \mathrm{~m}^{-3}\right.$ )as descriped by Klute (1986)are tabulated in Table (3).

Table(3):Values of field capacity (F.C., \%), wilting point (W.P., \%), available water (A.W., \%) and bulk density (Db, Kg. m-3).

\begin{tabular}{|l|c|c|c|c|}
\hline Depth, $\mathbf{c m}$ & F.C,\% & W.P,\% & A.W,\% & D $_{\mathbf{b}}\left(\mathbf{k g} \cdot \mathbf{m}^{-3}\right.$ ) \\
\hline $0-15$ & 47.6 & 25.9 & 21.7 & 1.13 \\
\hline $15-30$ & 43.5 & 23.6 & 19.9 & 1.18 \\
\hline $30-45$ & 39.2 & 21.3 & 17.9 & 1.24 \\
\hline $45-60$ & 37.1 & 20.2 & 16.9 & 1.31 \\
\hline Mean & 41.9 & 22.7 & 19.1 & 1.22 \\
\hline
\end{tabular}

\section{The drip irrigation system}

The experimental field is furnished with the drip irrigation system.In the drip irrigation, water is applied to each plant separately in a small, frequent, precise quantities through dripper emitters. It is the most advanced irrigation method with the highest application efficiency. The water is delivered continuously in drops at the same point and moves into the soil and wets the root zone vertically by gravity and laterally by capillary action. The planted area is only partially wetted. 


\section{Field experiments}

A field experiment was conducted usingfaba bean (Viciafaba L)as winter crop. Faba bean crop which was grown during the two seasons 2011/ 2012 and 2012/ 2013.

Dates of sowing $(\mathrm{S})$ and harvesting $(\mathrm{H})$ were as follows:

Season $1: \mathrm{S}=22 / 11 / 2011, \mathrm{H}=19 / 4 / 2012$

Season $2: \mathrm{S}=17 / 11 / 2012, \mathrm{H}=20 / 4 / 2013$

All cultural practices including laser leveling were performed as recommended by Agricultural Research Center (ARC) except for the factor of study i.e. effective irrigation management for faba bean crop under drip irrigation system.

\section{Total water applied (TWA)}

Total water applied consists of two items; irrigation water (IW) and rainfall (RF). Data of $R F$ is obtained from the agro- climatic station in the site. While IW is computed as follows:

$\mathrm{ET}_{\mathrm{c}}=\mathrm{ET}_{\mathrm{o}} \times \mathrm{Kc}$.

Where:

$\mathrm{ETC}=$ Crop evapotranspiration, $\mathrm{mm} \cdot \mathrm{day}^{-1}$

$\mathrm{Kc}=$ Crop coefficient.

The dimensionless crop coefficient, $\mathrm{Kc}$ is the ratio between water consumed by the growing crop (faba bean) to ETo. Values of Kc were quoted fromFAO Irrigation paper No. 56(Allen et al., 1998).

While applied irrigation water through the drip irrigation systems was computed as:

\section{ETc}

$\mathrm{IW}=\mathbf{E \mathbf { i }}$

As $_{i}$ is irrigation efficiency under drip irrigation which equals 0.85 .

Irrigation water was computed based on Reference evapotranspiration method $\left(\mathrm{ET}_{0}\right)$ as Main treatment.

Treatments:-

Main treatments (ET, methods):

A. FAO Penman Monteith.

B. Ibrahim.

C. Doorenbos and Pruitt.

D. Modified Penman.

Sub- treatment (Irrigation level).

1. Watering with $100 \% \mathrm{IW}$.

2. Watering with $80 \%$ IW.

3. Watering with $60 \%$ IW.

The investigated irrigation treatments were as follows:

A-FAO Penman-Monteith Method:

The FAO Penman-Monteith method as described by Allen et al. (1998) wasused to calculate ETo. The equation is given as: 


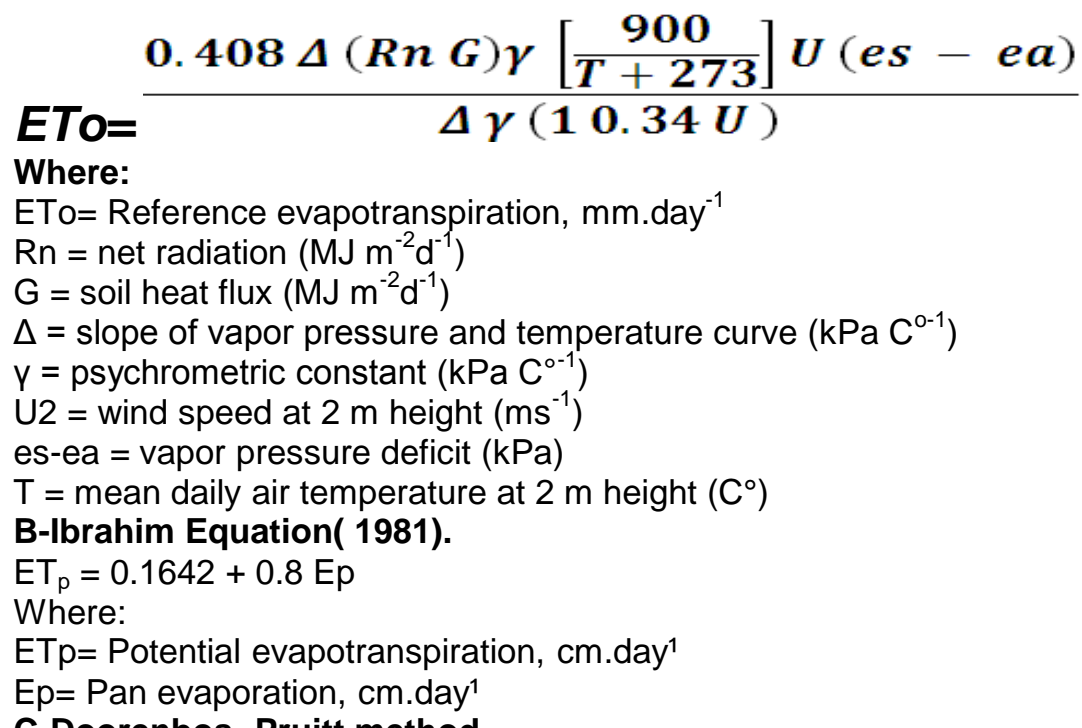

\section{C-Doorenbos- Pruitt method.}

Doorenbos- Pruitt (1975)predicted potential evapotranspiration(ETp as follows:

$$
\mathrm{ET}_{\mathrm{p}}=\mathrm{BWR} / \mathrm{L}-0.3
$$

\section{Where:}

$E T_{p}=$ daily potential evapotranspiration in $\mathrm{mm} /$ day.

$\mathrm{B}=$ adjustment factor based on wind and mean relative humidity.

$\mathrm{W}=$ weight factor based on temperature and elevation above sea level.

$\mathrm{R}_{\mathrm{s}}=$ daily total incoming solar radiation for the period of consideration in cal/ $\mathrm{cm}^{2} /$ day.

$\mathrm{L}=$ latent heat of vaporization of water in cal $/ \mathrm{cm}^{2} /$ day.

\section{D-Modified penman.}

Equation of the modified Penman method contains a radiation term and an aerodynamic term as follows:

$\mathrm{ET}_{0}=\mathrm{C}$ "W.Rn+(1-W).F(U).(e $\left.\mathrm{e}_{\mathrm{s}}-\mathrm{e}_{\mathrm{a}}\right)$ "

Where:

$\mathrm{ET}_{0}=$ referance crop evapotranspiration,

$\mathrm{C}=$ adjustment factor to compensate for the effect of day and night weather condition,

$\mathrm{W}=$ Weighting factor,

$\mathrm{R}_{\mathrm{n}}=$ net radiation in equivalent evaporation ( $\mathrm{mm} . /$ day).

$\mathrm{E}_{\mathrm{a}}=$ Actual vapour pressure, $(\mathrm{mm} . \mathrm{Hg})$.

$E_{s}=$ Saturation vapour pressure at air temperature.

$$
E_{a}=E_{s} \times \frac{R H}{100}
$$

\section{Data collection}

Irrigation water.

Rainfall.

Seed yield. 


\section{RESULTSAND DISCUSSIONS}

Irrigation water (IW), rainfall (RF) and total Water applied (TWA).

AS stated before in the materials and methods, total water applied (WA) consists of two components e.g. irrigation water (TIW) and rainfall (RF). Therefore, the values of IW, RF and TWA for the two growing seasons $2011 / 2012$ and $2012 / 2013$ of the investigated faba bean crop are tabulated in Table ( 4$)$. Values are representing in $\mathrm{m}^{3} / \mathrm{fed}$.and $\mathrm{cm}\left(1 \mathrm{fed} .=4200 \mathrm{~m}^{2}=\right.$ $0.38 \mathrm{ha})$.

Regarding irrigation water (IW), the values can be arranged in descending order in connection with the different reference evapotranspiration $\left(\mathrm{ET}_{0}\right)$ methods as; Modified penman, Ibrahim, Doorenbos and Pruit and FAO Penman - Monteith in the first season. While the arrangement in the second season is; Ibrahim, Modified Penman, Doorenbos - Pruit and FAO Penman-Monteith $\mathrm{ET}_{0}$ methods.

Therefore, FAO Penman-Monteith is resulted in the lowest value of IW in the two seasons of faba bean. On the other hand, modified Penman and Ibrahim methods are associated with the highest value of IW in the first and the second season, respectively.

In connection with irrigation level; the amount of IW has the same trend with that of irrigation level. Meaningfully for each $\mathrm{ET}_{0}$ method, IW under $100 \%$ level is the highest followed by $80 \%$ and the $60 \%$ is the lowest.

As tabulated in Table (4-a-b), seasonal rainfall (RF) in the growing season of faba bean is 411.84 and $398.33 \mathrm{~m}^{3} / \mathrm{fed}$. or 9.81 and $9.48 \mathrm{~cm}$, respectively in the first and second growing season.

So, by adding RF to IW for each stated irrigation level (100, 80 and $60 \%$ ) under each reference evapotranspiration $\left(E_{0}\right)$ method, then total water applied (TWA) could be obtained. In general, WA has the same trend with that of IW.

Average values of IW, RF and WA are tabulated in Table (4-c ). Regarding IW, the highest mean values under the $100 \%$ irrigation level are ranged between 566.0 and $696.41 \mathrm{~m}^{3} / \mathrm{fed}$.which resulted from FAO PenmanMonteith and modified Penman method, respectively. On the other hand, the corresponding lowest mean values 476.83 and $533.55 \mathrm{~m}^{3} / \mathrm{fed}$. is recorded under the $60 \%$ irrigation level. Mean values of IW under the $80 \%$ level are in between.Mean value of rainfall in the two seasons is $405.09 \mathrm{~m}^{3} / \mathrm{fed}$. that it is a reasonable amount in irrigation water in the North Nile Delta, particularly for winter crops such as faba bean.Therefore, total water applied (WA) has the same trend with that of irrigation water (IW). Meanwhile, TWA is ranged between 881.92 and $1101.50 \mathrm{~m}^{3} / \mathrm{fed}$. The stated values are resulted under the $60 \%$ irrigation level of FAO Penman-Monteith and the $100 \%$ irrigation level of modified Penman. 
El-Hadidi,M.E. et al.

T4 
The obtained results are in the same line with that obtained byMashari and Naeem (2008), Ali and Talukder (2008) and Oweis and Hachuns (2006). Contribution of rainfall (RF) in total water applied (TWA):

Values of contribution percentages of RF in TWA as tabulated in Table ( 4- c) cleared out that this percentages have the opposite trend with that of irrigation level. For example, with applied Ibrahim method, the mean contribution percentages are; 37.36, 39.79 and 42.58 under 100,80 and $60 \%$ irrigation level of this method, respectively. The corresponding values for FAO Penman-Monteith are; $41.79,43.79$ and $45.98 \%$. Same findings are obvious with all investigated $\mathrm{ET}_{0}$ methods.

So, in conclusion this finding of sharing rainfall in total water applied should be taking into consideration which is considered as an effective way of water saving in rationalize faba bean watering. Nearly, half of TWA is coming from rainfall. This contribution is mainly depending upon the level of applied irrigation water e.g. 60,80 or $100 \%$. This finding is in the same direction with that stated by oweis and hachuns (2006).

Rate of water applied:

Seasonal rate of irrigation water applied (WA) as expressed in $\mathrm{m}^{3}$ /feddan/day under drip irrigation system is tabulated in Table (4-c ). Values are ranged between 5.68 and $7.09 \mathrm{~m}^{3} / \mathrm{fed}$./day which was resulted under the $60 \%$ of FAO Penman-Monteith and under the $100 \%$ of modified Penman.

This parameter of seasonal rate of water applied is useful in planning effective water management for faba bean crop under drip irrigation system with taking into consideration the availability of irrigation water. Out of the stated values, nearly $50 \%$ is coming from rainfall. Meaningfully, average seasonal daily irrigation water applied (IW) is ranged between 2.84 and 3.55 $\mathrm{m}^{3} / \mathrm{fed}$. depending upon the availability of irrigation water and the obtained marketable yield.

Seed yield (ton/ feddan).

Table (5) illustrated that no significant difference among different treatments from seed yield point of view. This result could be attributed to the effect of rainfall which diminishing the role of irrigation water on seed yield.

Table (5). Effect of different ET methods and water deficit on faba bean seed yield (ton/ fed).

\begin{tabular}{|c|c|c|c|c|c|c|c|c|c|c|c|}
\hline \multirow[t]{2}{*}{ Sea } & $\begin{array}{r}\text { FAC } \\
\text { M }\end{array}$ & $\begin{array}{l}\text { Penn } \\
\text { lonteit }\end{array}$ & $\begin{array}{l}\operatorname{man}- \\
\text { th }\end{array}$ & \multicolumn{3}{|c|}{ Ibrahim } & \multicolumn{3}{|c|}{$\begin{array}{c}\text { Doorenbos- } \\
\text { Pruitt }\end{array}$} & \multicolumn{2}{|r|}{$\begin{array}{l}\text { Modified } \\
\text { penman }\end{array}$} \\
\hline & $100 \%$ & $80 \%$ & $60 \%$ & $100 \%$ & $80 \%$ & $60 \%$ & $100 \%$ & $80 \%$ & $60 \%$ & $100 \%$ & \begin{tabular}{|l|l|}
$80 \%$ & $60 \%$ \\
\end{tabular} \\
\hline & 1.93 & 2.5 & 2.12 & 1.82 & 1.7 & 1.8 & 1.99 & 2.02 & 1.64 & 2.35 & \begin{tabular}{|l|l|}
2.14 & 1.77 \\
\end{tabular} \\
\hline 12 season & 1.69 & 1.74 & 1.62 & 1.73 & 1.68 & 1.68 & 1.80 & $\begin{array}{ll}1.57 \\
\end{array}$ & 1.60 & \begin{tabular}{|l|}
1.66 \\
\end{tabular} & \begin{tabular}{|l|l|}
1.79 & 1.73 \\
\end{tabular} \\
\hline
\end{tabular}

Therefore, it is recommended to irrigate faba bean with $60 \%$ irrigation water based on FAO Penman - Monteith or Ibrahim methods depending upon the availability of climate elements. This finding could be practiced under drip irrigation only. 


\section{REFERENCES}

Abu-Zeid, M. and A. Hamdy (2002).Water crisis and food security in the Arab world: where we are and where do we go. 2nd Regional Conference on Arab Water, Cairo, Egypt, 2002, p. 6.

Ali, M. H; and M. S. U. Talukder (2008).Increasing Water Productivity in Crop Production. A Syntheses Agriculture Water Management, pp. 12011213.

Allen, R. G; L. S. Pererira; D. Raes and M. Smith (1998).Crop evapotranspiration: Guidelines for computing crop water requirements. FAO Irrigation and Drainage Paper No. 56. FAO, Rome, Italy.

Ashry, M.R.K; Farrag, F.R.M; Abdu,S.M.M. and El- Akram,M.F.I (2012). Rationalization of irrigation water use for faba bean (viciafaba L.). FayoumJ.Agric.Res. \& Dev., Vol. 26, No.1, January, 2012.

Dewis , J; and F. Fertias (1970)." Physical and Chemical Methods of Soil and Water Analysis" : Soil Bulletin No. 10 FAO. Rome.

Doorenbos, J., and W. O .Pruitt (1975).Crop water requirements. Irrigation and drainage paper, No. 24, FAO, Rome.

Garcia , G. (1978 ). Soil Water Engineering Laboratory Manual . Colorado State University .Dept of Agric and Chemical Engineering . Fort Collins , Colorado , USA

Hesse , P.R (1971). «A Text Book of Soil Chemical Analysis » Juan Murry( publisher ) Ltd , London .Ibrahim, M.A.M. (1981). Evaluation of different methods for calculating potential evapotranspiration in North Nile Delta region.ph.D. Thesis,Fac.Agric.Soil, Water Sci., Alex.Univ.

Jackson , M.L.( 1967). "Soil Chemical Analysis » Practice Hall of India private limited, New Delhi.

Kijne, J.W.; R. Barker and D. Molden (2003).Water Productivity in Agriculture: Limits and Opportunities for Improvement,Comprehensive Assessment of Water Management in Agriculture Series, No. 1 International Water Management Institute, Srilanka.

Klute , A(ed) (1986). Methods of Soil Analysis. Part 1: Physical and Mineralogical Methods. American Socially of Agron Madison Wisconsin, USA.

Mashari A. Al- Naeem (2008).Effect of irrigation scheduling on growth parameters and water use efficiency of barely and faba bean crops in Al- Asha, Saudi Arabia. American Jornal of plant physiology 3(3): 111120.

Oweis, T. and A. Hachuns (2006).Water treatments and supplemented irrigation for improved water productivity of dry farming systems in west Asia and Africa. Agric. Water Manage,J. 80: 57-73.

Phocaides, A. (2007). Handbook on pressurized irrigation techniques.FAO. Rome. 
كمية مياه الري الواجب إضافتها لمحصول الفول البلدي تحت الري التنقيط وعجز

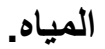

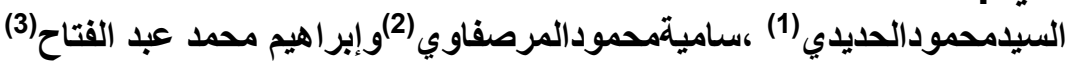

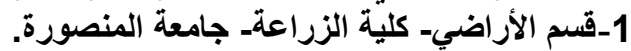

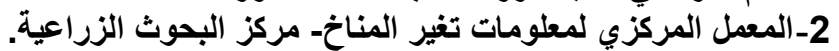
3-معه بحوث الاراضي والمياه والبيئة مركز البحوث مرك الزراعية.

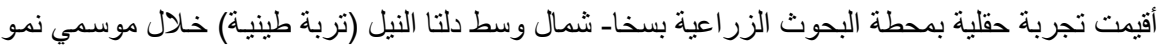

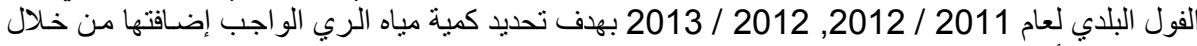

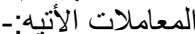

أربعة معاملات رئيسية ألا وهي طرق تقدير البخر نتح المرجعي ( فاو بنمان مونتيث- إبراهيم- دورنبوس

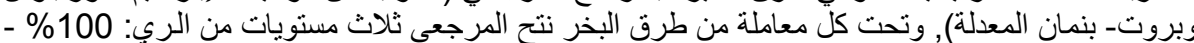
\%60 - \%80

وقد تمت إضافة مياه الري من خلال شبكة الري بالتنقيط.

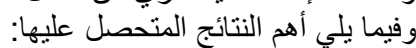
• متوسط مياه الري (IW) يتراوح بين 476.8 - 696.4 م²/ فدان و التي تحصل عليها من الـ 60\% فاو

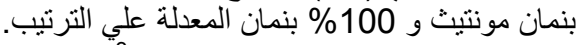

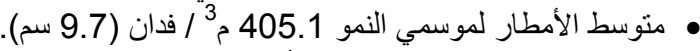
• متوسط المياه المضافة (الري + الأمطار ) لها نفس إنجاه مياه الري ولان والتي تتراوح بين 881.9 - 1101.5

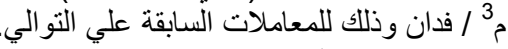

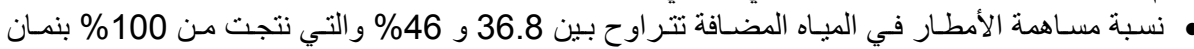

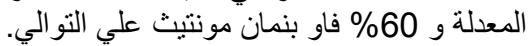

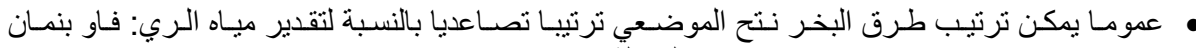

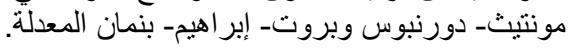

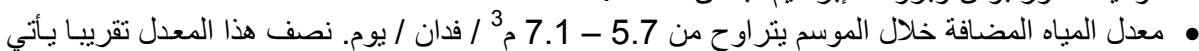

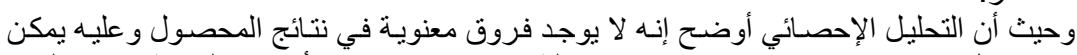

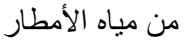

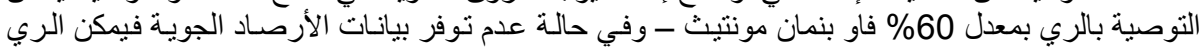

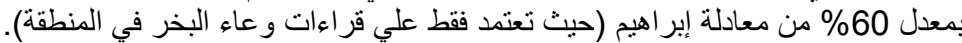

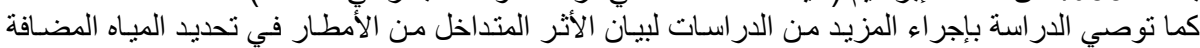



كلية الزراعة - جامعة المنصورة مركز البحوث المائية
قام بتحكيم البحث

أ.د / أحمد عبد البحث القادرطة

أ.د / محمد ابراهيم مليحة 
El-Hadidi,M.E. et al. 
Table (4). Seasonal irrigation water (I.W), rainfall (RF), total water applied (TWA), Percentage of RF to WA and rate of water applied $\left(\mathrm{m}^{3} / \mathrm{fed} / \mathrm{day}\right)$.

a- $\quad 1^{\text {st }}$ season 2011-2012.

\begin{tabular}{|c|c|c|c|c|c|c|c|c|c|c|c|c|}
\hline parameter & FAO-P & nman $\mathrm{m}$ & onteith & & Ibrahim & & Doo & enbos\& & Pruit & Mod & fied Pen & nan \\
\hline & $100 \%$ & $80 \%$ & $60 \%$ & $100 \%$ & $80 \%$ & $60 \%$ & $100 \%$ & $80 \%$ & $60 \%$ & $100 \%$ & $80 \%$ & $60 \%$ \\
\hline IW, $\mathrm{m}^{3} / \mathrm{fed}$ & 525.60 & 487.15 & 448.15 & 584.28 & 534.09 & 483.91 & 544.38 & 502.15 & 459.95 & 678.63 & 552.15 & 497.45 \\
\hline $\mathrm{cm}$. & 12.51 & 11.60 & 11.60 & 13.91 & 12.72 & 11.52 & 12.96 & 11.96 & 10.95 & 16.16 & 13.15 & 11.84 \\
\hline $\mathrm{RF}, \mathrm{m}^{3} / \mathrm{fed}$ & 411.84 & 411.84 & 411.84 & 411.84 & 411.84 & 411.84 & 411.84 & 411.84 & 411.84 & 411.84 & 411.84 & 411.84 \\
\hline $\mathrm{cm}$. & 9.81 & 9.81 & 9.81 & 9.81 & 9.81 & 9.81 & 9.81 & 9.81 & 9.81 & 9.81 & 9.81 & 9.81 \\
\hline WA, $\mathrm{m}^{3} / \mathrm{fed}$ & 937.44 & 898.99 & 860.54 & 996.12 & 945.93 & 895.75 & 956.22 & 913.99 & 871.79 & 1090.47 & 963.99 & 909.29 \\
\hline $\mathrm{cm}$. & 22.32 & 21.40 & 20.49 & 23.72 & 22.52 & 21.33 & 22.77 & 21.76 & 20.76 & 25.96 & 22.95 & 21.65 \\
\hline RF/WA,\% & 43.93 & 45.81 & 47.86 & 41.34 & 43.54 & 45.98 & 43.07 & 45.06 & 47.24 & 37.77 & 42.72 & 45.29 \\
\hline RateWA, $\mathrm{m}^{3} /$ day/fed & 6.29 & 6.03 & 5.78 & 6.69 & 6.35 & 6.01 & 6.42 & 6.13 & 5.85 & 7.32 & 6.47 & 6.10 \\
\hline
\end{tabular}

\section{b- $\quad 2^{\text {nd }}$ season $2012-2013$}

\begin{tabular}{|c|c|c|c|c|c|c|c|c|c|c|c|c|}
\hline \multirow[t]{2}{*}{ parameter } & \multicolumn{3}{|c|}{ FAO-Penman monteith } & \multicolumn{3}{|c|}{ Ibrahim } & \multicolumn{3}{|c|}{ Doorenbos\&Pruit } & \multicolumn{3}{|c|}{ Modified Penman } \\
\hline & $100 \%$ & $80 \%$ & $60 \%$ & $100 \%$ & $80 \%$ & $60 \%$ & $100 \%$ & $80 \%$ & $60 \%$ & $100 \%$ & $80 \%$ & $60 \%$ \\
\hline IW, $\mathrm{m}^{3} / \mathrm{fed}$ & 606.40 & 555.68 & 504.96 & 795.48 & 706.94 & 618.41 & 631.26 & 575.57 & 519.88 & 714.19 & 641.91 & 569.64 \\
\hline IW cm. & 14.44 & 13.23 & 12.02 & 18.94 & 16.83 & 14.72 & 15.03 & 13.70 & 12.38 & 17 & 15.28 & 13.56 \\
\hline $\mathrm{RF}, \mathrm{m}^{3} / \mathrm{fed}$ & 398.33 & 398.33 & 398.33 & 398.33 & 398.33 & 398.33 & 398.33 & 398.33 & 398.33 & 398.33 & 398.33 & 398.33 \\
\hline $\mathrm{RF} \mathrm{cm}$. & 9.48 & 9.48 & 9.48 & 9.48 & 9.48 & 9.46 & 9.46 & 9.46 & 9.46 & 9.46 & 9.46 & 9.46 \\
\hline WA, $\mathrm{m}^{3} / \mathrm{fed}$ & 1004.73 & 954.01 & 903.29 & 1193.81 & 1105.27 & 1016.74 & 1029.59 & 973.90 & 918.21 & 1112.52 & 1040.24 & 967.97 \\
\hline WA cm. & 23.92 & 22.71 & 21.51 & 28.42 & 26.32 & 24.21 & 24.51 & 23.19 & 21.86 & 26.49 & 24.77 & 23.05 \\
\hline RF/WA,\% & 39.65 & 41.75 & 44.10 & 33037 & 36.04 & 39.18 & 38.69 & 40.90 & 43.38 & 35.80 & 38.29 & 41.51 \\
\hline Rate WA, $\mathrm{m}^{3} / \mathrm{d}$ & 6.20 & 5.89 & 5.58 & 7.37 & 6.82 & 6.28 & 6.36 & 6.01 & 5.67 & 6.86 & 6.42 & 5.98 \\
\hline
\end{tabular}

\section{c. Average of the two seasons.}

\begin{tabular}{|c|c|c|c|c|c|c|c|c|c|c|c|c|}
\hline \multirow[t]{2}{*}{ parameter } & \multicolumn{3}{|c|}{ FAO-Penman monteith } & \multicolumn{3}{|l|}{ Ibrahim } & \multicolumn{3}{|c|}{ Doorenbos\&Pruit } & \multicolumn{3}{|c|}{ Modified Penman } \\
\hline & $100 \%$ & $80 \%$ & $60 \%$ & $100 \%$ & $80 \%$ & $60 \%$ & $100 \%$ & $80 \%$ & $60 \%$ & $100 \%$ & $80 \%$ & $60 \%$ \\
\hline $\mathrm{IW}, \mathrm{m}^{3} / \mathrm{fed}$ & 566.0 & 521.42 & 476.83 & 689.88 & 620.52 & 551.16 & 587.82 & 538.86 & 489.92 & 696.41 & 597.03 & 533.55 \\
\hline$W A, m^{3} /$ fed & 971.09 & 926.50 & 881.92 & 1094.97 & 1025.60 & 956.25 & 992.91 & 943.95 & 895.00 & 1101.50 & 1002.12 & 938.63 \\
\hline RF/WA,\% & 41.79 & 43.79 & 45.98 & 37.36 & 39.79 & 42.58 & 40.88 & 42.98 & 45.31 & 36.79 & 40.51 & 43.22 \\
\hline $\begin{array}{l}\text { Rate } \\
\text { WA, } \mathrm{m}^{3} / \text { day/fed }\end{array}$ & 6.25 & 5.96 & 5.68 & 7.03 & 6.59 & 6.15 & 6.39 & 6.07 & 5.76 & 7.09 & 6.45 & 6.04 \\
\hline
\end{tabular}




\section{El-Hadidi,M.E. et al.}

